Paulina Urbańczyk

Uniwersytet Gdański

\title{
Twórcze opowieści nocy. Zaniedbane przedstawienia senne
}

$\mathrm{Na}$ jednostkową perspektywę postrzegania świata wpływa indywidualny sposób jego pojmowania oraz wyobrażenia o nim. W dużej mierze posługujemy się utartymi schematami, stereotypami myślowymi, symbolami ze stale przypisanym w kulturze znaczeniem, ale oprócz tego sami jesteśmy kreatorami kultury i wyobrażeń. Szczególne miejsce wśród kreatorów usymbolizowanych wyobrażeń własnych i wyobrażeń wspólnoty ma artysta.

Światy wyobrażone jednak nie są wyłącznie domeną twórczości artystycznej, każdy bowiem fantazjuje i śni, a więc tworzy własną fikcję, osobisty mit.

Sny przytrafiają się każdemu i powinny interesować każdego, kto dba o własną psychikę i wyobraźnię. I chyba interesują, choć tylko mimochodem i na chwilę. Wystarczy wspomnieć o dziedzinie nauki zajmującej się badaniami nad snem, by rozmówca spojrzał na nas ze sceptycyzmem (coś jak w przypadku ezoterycznej perspektywy w metodologii badań itp.), i natychmiast po zwątpieniu odczuł potrzebę opowiadania o własnych marzeniach sennych. Jest to zachowanie tym ciekawsze, że odsyła nas do samego postrzegania czy stosunku do snów większości śniących. Wydaje się, że nieodparta chęć do zwierzeń z przeżyć onirycznych wiąże się z przeczuciem, że te, często nielogiczne, nocne historie mogą mieć jakieś znaczenie. Z drugiej strony przecież całą obecną we śnie intymność chroni i skrywa armia metafor, symboli czy po prostu niedosłowności, dzięki którym śniący ze swobodą opowiada o tak prywatnym świecie wyobrażeń, których nie czuje się de facto ani właścicielem, ani twórcą, nie utożsamia się z nimi. Są tylko jakby jego.

W artykule tym przypomnę o snach jako o podstawowej symbolicznej aktywności umysłu. Pokazując teorie na temat miejsc wspólnych snów i fikcji artystycznej, zapytam, czy lekceważenie własnych snów nie jest ignorancją wobec osobistych wyobrażeń, przeżywania i pojmowania świata. Chciałoby się rzec: sny to kłamstwa, które mogą szeptać pewną prawdę i przyczyniać się do samopoznania. 
Pokażę kilka ognisk rozległego tematu relacji symbolicznego śnienia (przedstawienia) i kreacji artystycznej na tle badań samopoznania i zastanowię się, jak wiedza osób związanych z literaturą i sztuką może wpływać na badania snów, a także czy możemy zbliżyć się do własnego profilu śnienia, jeśli potraktujemy je jako twór zbliżony do artefaktu. Celem artykułu jest zwolnienie interpretacji snów od ciężaru, w który wyposażyła go teoria psychoanalityczna. Porównuję dzieło literackie czy artefakt w ogóle z marzeniem sennym, by pokazać, że wycieczki samopoznawcze można rozpocząć od zabawy. Można użyć $\mathrm{w}$ tej grze relaksu zamiast walki, mocowania się z ciężkimi zasłonami cenzury czy mechanizmów obronnych w marzeniach sennych. Literatura użyta $\mathrm{w}$ artykule nie jest wyczerpująca, a sam tekst ma charakter wstępny. Jest bardziej szkicownikiem aniżeli skończoną całością. Same sny przecież mają charakter szkiców, a celem tekstu jest odurzenie swobodą strachu przed własnymi "demonami", toteż pozwalam sobie na tę nonszalancję.

Publikacja dotyczy światów wyobrażonych - czy można zaproponować bardziej ogólny temat dla humanistyki, kiedy przyjmiemy za Schopenhauerem, że nie mamy nic ponad to?

Wiele jest teorii na temat literatury i sztuki, również perspektywy badania snów ulegają pomnożeniu: poczynając od psychoanalizy, egzystencjalizmu, fenomenologii, metody ilościowej Calvina Halla, na parapsychologii czy ezoteryce kończąc. Każda teoria na swój sposób rozumie funkcje marzeń sennych, aczkolwiek niemal dla wszystkich istotnym pojęciem jest symbol. Skupię się tutaj głównie na psychoanalitycznych teoriach snów oraz związkach twórczości artystycznej i śnienia.

Istnieje wiele więzi między psychoanalizą i sztuką. Sigmund Freud interpretuje literaturę, posługuje się nią do wytłumaczenia procesów psychicznych. To tam znajduje przedstawienia kompleksów, na których buduje podstawowe tezy. Psychoanalityczne interpretacje sztuki mają bardzo różne odmiany. Skrajnie upraszczając, można sprowadzić je do dwóch form pracy z tekstem: strukturalnej lub genetycznej (Fiała 1991). Pierwsza metoda jest jak psychokrytyka (Mauron 1976) - skupia się na powtarzanych w różnych artefaktach natrętnych fantazjach, motywach. Druga metoda natomiast opiera analizę dzieła na rzeczywistej biografii autora.

Zacznijmy od fantazji. Miewamy je, zdaje się, wszyscy: widzimy siebie w samolocie podczas wycieczki w nieznane, odnoszących sukcesy, rządzących, szczęśliwych, projektujemy kojące hipotezy, najczęściej dotyczące przyszłych zdarzeń, rozwiązań alternatywnych. Tego typu codzienne fantazjowanie odsyła do klasycznej interpretacji Freuda zasady przyjemności i spełnionego życzenia. Czym jednak od zwykłych fantazji różnią się dzieła literackie i sny?

Według psychoanalitycznych teorii wyobraźnia, impuls twórczy artysty i sen mają podobne źródło, czyli szeroko pojęte nieświadome fantazje. U Freuda impuls twórczy zostaje odtworzony w fabule dzieła literackiego. Wydaje się więc, że niezależnie od rodzaju utwór - surrealistyczny, naturalistyczny czy poetycki nieświadomą fantazję może uporządkować świadoma myśl twórcza i przedstawić za pomocą narracji, która w takim odniesieniu ma zawsze charakter symboliczny ${ }^{1}$

${ }^{1}$ Przy czym terminu "symbol” Freud, Fromm i wielu innych używa przede wszystkim do określenia stałych, archetypowych - podobnie jak w ujęciu krytyki tematycznej - obrazów we 
zgodnie z dynamiką tak zwanego przesunięcia - gdzie symbol zastępuje treści psychiczne.

Literatura i sztuka - oprócz tego, że są źródłem przeżycia estetycznego i poznania - mogą być także bodźcem do samopoznania. Przez nienaukowe traktowanie marzeń sennych ich autoanalityczna funkcja została pominięta. W sytuacji postrzegania snów jako „innej formy myślenia” (Freud 2007) i bądź co bądź kreatywną aktywność psychiki brak zainteresowania marzeniami nocnymi jest zniewagą dla wyobraźni.

Proces twórczy literata czy artysty wiąże się z obcowaniem z własnymi wyobrażeniami i porządkowaniem ich. Według Freuda „fantazja artysty musi utracić swój egocentryczny charakter, aby osiągnąć stan zgodności ze sztuką" (Freud 1986: 515) ${ }^{2}$. To znaczy zostaje opracowana narzędziami świadomego aktu twórczego. A „powieść psychologiczna zawdzięcza swój charakter skłonności pisarza do rozszczepienia ego przez obserwację samego siebie - na wiele ego cząstkowych" (Freud 1991: 514) - na bohaterów.

Skoro artyście zdarza się dotykać w impulsie twórczym nieświadomego myślenia, to dlaczego nie przedstawia swoich odczuć wprost i nie pisze rozprawy psychologicznej, nie wykłada nam teorii? Po pierwsze nie każde dzieło jest rozpisaniem psychologicznie głębokich treści lub nie jest tym dla wszystkich. Kiedy twórca natomiast dotyka psychologii tych zagadnień, jego praca przypomina odtwarzanie w pamięci czegoś, co ukazuje się tylko na chwilę, i to mgliście - jako impuls jest intensywne, ale zarazem niejasne. Być może w zgodzie z psychoanalityczną wykładnią artysta dąży do stworzenia tego, co w impulsie twórczym już się wydarzyło, wydarzyło się "tak jakby"3, a co może pojawić się wyłącznie przy pomocy języka sztuki, ponieważ jedynie język artystyczny - symbol, przesunięcie, metafora - może zaprezentować coś, co pozostaje dla podmiotu autorskiego nie do końca wyraziste. Sposobem opowiedzenia o tym może być wyłącznie materia - zawsze otwarta na wieloznaczność odczytań. Jest to pewego rodzaju prezent dla czytelników, których udziałem bywa tu także przyjemność, jaka „wpływa z wyzwolenia się psychiki z napięć" (Freud 1991: 517). Nieświadoma myśl inicjująca proces twórczy może pozostać więc bezpośrednio nienazwana, choć powołuje do istnienia świat artystycznej fabuły i jej rezultatem jest wyzwolenie z napięć. Zupełnie jak w przypadku snów, gdzie treść jeszcze nieubrana w słowa staje się tworzywem obrazów.

W klasycznym ujęciu psychoanalitycznym sen jest spełnionym życzeniem ponad zasadami nad-ja, a powstaje na skutek pracy myśli snu. „Oczywiście marzenie senne odpowiada [...] postępowaniu, przestrodze, zastanowieniu się, przygotowaniu lub próbie rozwiązania pewnego zadania [...] lecz [...] odnosi się to wszystko tylko do myśli ukrytych, które zostały przekształcone w marzenie senne" (Freud 2006: 203). A ono zawsze wyraża spełnienie życzenia, o czym Freud

śnie jak słońce, ogień, woda itp. Ja zaś używam tu pojęcia symbolu w znaczeniu szerszym, gdzie przesunięcie-metonimia, reprezentacja jest rodzajem symbolicznego przedstawienia. Jeżeli na przykład we śnie $\mathrm{z}$ łatwością zrywam złoty łańcuszek $\mathrm{i}$ wiążę to $\mathrm{w}$ interpretacji $\mathrm{z}$ podobnie zakończonym związkiem, przedstawienie także ma charakter symboliczny, metaforyczny.

${ }^{2}$ Stąd Segal twierdzi, że proces twórczy wymaga odrzucenia, „,modyfikacji zasady przyjemności” i „zajęcia pozycji depresyjnej”. Dzięki temu fabuła jest bardziej złożona. Stwierdza, że „marzenia senne to wydzieliny stłamszonych w zarodku myśli".

${ }^{3}$ Segal mówi w kontekście marzeń sennych o rzeczywistości „tak jakby”, ,jak gdyby". 
wnioskuje na podstawie praktyki i poprzez przyłożenie głównej właściwości marzeń sennych dzieci do snów dorosłych.

U Freuda pojawia się teza, że sam proces symbolizacji i tworzenia się marzenia sennego jest rezultatem mechanizmów obronnych, które przesuwają, zniekształcają, oddalają intencję myśli sennych. Delikatnego osłabienia wymaga tu chyba podejście zanadto negatywne, gdyż skoro nieświadomość jest dla nas absolutnie abstrakcyjna, a chce dojść do głosu we śnie, to musi użyć do niego jakichś środków, posłużyć się jakimś językiem. Oczywiście możemy sobie wyobrazić, że sny (koncentruję się na snach metaforycznych, kreatywnych, symbolicznych) mogłyby być mniej zagmatwane i łatwiejsze do wyjaśnienia.

Badacz snów, kognitywista Calvin Hall, dyskutując z koncepcją Freuda, widzi sny jako procesy nieskomplikowane, a proste. Uważa, że wszystkie sny są po prostu serią symbolicznych obrazów, które wyrażają konkretne idee, pomysły, wyobrażenia (Hall 1953: 184-186). A przyczyną symbolicznej natury snów nie jest cenzura i opór, lecz sposób obrazowania, coś zbieżnego z Adlerowskim stylem życia.

Kiedy jednak zauważymy, że - jak wiadomo - nieświadomość nie jest siebie świadoma, to wiemy przecież, że jest ona świadomości nieznana i chce wyrazić myśli/impulsy, których świadomość już nie pamięta, których mogła jeszcze nie pomyśleć lub które są dla niej jeszcze „nie do pomyślenia”. Próbując przekazać własną intencję, posługuje się ona obrazami skojarzonymi symbolicznie z tą intencją, układa je w spójne fabuły. Dodatkowo nieświadomość nie tylko korzysta z materiału widzianego, słyszanego, doświadczonego, ale potrafi kreować (jeśli to nie tylko złudzenie) nowe światy, miejsca, osoby, zdarzenia. Można pomyśleć, że sen wybiera przedstawienia symboliczne i niedosłowne poniekąd właśnie po to, by ubrać w znaczenia rzeczy, które niejednokrotnie po prostu jeszcze nie były pomyślane, konteksty, które są dla świadomości nowe lub są myślami niedokończonymi. I w tej próbie, będąc de facto sama niezrozumiana, bez niezbędnych przedstawień i zapośredniczeń posługuje się nie tylko mechanizmami obronnymi, pracą cenzora, oporów i instancji ograniczających przepływ wiadomości, ale także po prostu wsobną, czystą, prototypową kreatywnością, podstawowym, twórczym obrazowaniem. Bo czy nie za łatwo jest zgodzić się, że nowa przestrzeń w snach jest tylko wytworem oporów? Czy w każdym śnie tak bardzo musimy się bronić przed samymi sobą ${ }^{4}$ ? Czy to częstokroć nie jest cenzura, a raczej styl i forma przedstawienia, rodzaj metafory? Wydawać by się mogło, że jest to tylko nowa, złagodzona znaczeniowo wersja obrony ego przed treściami wypartymi za pomocą mechanizmów obronnych bądź kreatywności (być może tylko jako sposób ich wyrażenia). Najmocniejsza w teorii zniekształcania jest chwila, gdy we śnie dochodzi do przesunięcia akcentów afektywnych, którego celem ma być cenzura i efekt niezrozumienia (Freud 1995).

Wracając jednak do egoistycznego charakteru fantazji, wygładzanego przez symbolikę procesu twórczego, można zastanowić się, czy to sama fantazja może dotyczyć psychicznych właściwości całych wspólnot (bo właśnie aspekt wspólnotowy zdaje się zapewniać dziełu walor podniecający czytelników ponad granicami kultur czy epok, a więc nadający mu charakter arcydzieła), czy też wspólnotowy charakter uzyskuje artysta wyłącznie poprzez jakość opracowania fantazji.

\footnotetext{
${ }^{4}$ Kognitywiści również uważają, że symbol raczej ujawnia, aniżeli ukrywa.
} 
Prawdopodobnie jest to zespolenie tych dwóch elementów - czegoś bardzo istotnego w kontekście ponadjednostkowym i genialnej intuicji artysty, który ubiera w doskonałe estetycznie przedstawienie to, czego doświadczył w impulsie twórczym. Arcydzieła - przekazujące coś ponad czasem i indywidualnością ${ }^{5}$ - były także zainteresowaniem ojca psychoanalizy - przypomnijmy choćby analizę twórczości Leonarda da Vinci czy Dostojewskiego.

Fabuła dzieła literackiego czy artystycznego jest przeto bardziej złożona niż charakter samej fantazji. Proces twórczy otula ją bowiem warsztatem dekoratorskim, a także rozbudowuje, pogłębia, i rozciąga, rozwijając pierwotną myśl. W marzeniach nocnych natomiast silny udział świadomości w opracowywaniu wypowiedzi sennej nie jest możliwy (sny jasne to rzadkość). Tutaj przepracowania treści nieświadomych fantazji nie dokonuje artysta, a marzenia senne ${ }^{6}$ i dopiero później może stać się przedmiotem analizy. Freud wyraźnie rozgranicza pracę myśli sennych i samo marzenie senne, co przypomina zależności między impulsem twórczym i fabułą literacką.

To nie literatura jest jak sen, a raczej praca artysty, którego spotka psychoanalitycznie rozumiany impuls twórczy ${ }^{7}$, jest podobna do pracy snu: szczególnie gdy pod uwagę weźmiemy naturalną niemożność dosłownego przedstawienia. Choć z perspektywy psychoanalizy cele są tutaj całkiem inne - artysta próbuje rozpisać, nadać strukturę myśli zawartej w twórczym impulsie, a cenzura senna poprzez wpływ na myśli senne zataja je, „zniekształca” - jak pejoratywnie określa to Freud - ich znaczenie pierwsze, proponując symboliczne przedstawienie. Artysta chce zbliżyć się przez przedstawienie, zataić sen. W tym ujęciu psychoanaliza zakłada pewną samokontrolę, samoświadomość cenzury, która ma funkcjonować zgodnie z rozpoznaną przez Freuda intencją.

A czy nie może być po prostu tak, że rzeczywiście aparat psychiczny potrzebuje podjęcia namysłu nad doświadczeniem podczas snu? Chce podsuwać rozwiązania, koić, spełniać życzenia, ale postępuje przy tym trochę jak artysta czy pisarz z przedstawionego modelu. Intencje senne pojawiają się u bram snu jako impulsy, których autorka - nieświadomość - nie jest świadoma, gdyż jest nieświadomością nieświadomą również samej siebie. Próbuje ona przy częściowym udziale świadomości - trochę jak artysta - wyrazić treści doświadczenia poprzez obrazy i przede wszystkim dać wyraz towarzyszącym im wartościom emocjonalnym. Bo jak przywołuje Freud „wprawdzie rozbójnicy są wyimaginowani, ale lęk jest prawdziwy" (Freud 2007), "treść afektywna marzenia sennego pozostała wolna od zniekształcenia, które dotknęło treść wyobrażeniową" (Freud 2007).

5 Tak Jung pisze o dziełach stworzonych z impulsu ponadświadomego: „[...] należałoby nastawić się na coś ponadosobowego, co zakres świadomego rozumienia twórcę przekracza właśnie o tyle, o ile jego świadomość zdystansowana jest przez rozwój jego dzieła. Należałoby tu oczekiwać obcości obrazu i formy, pojawienia się myśli, które można pojąć jedynie intuicyjnie, języka, którego bogate w treść wyrażenia miałyby wartość prawdziwych symboli, ponieważ w najlepszy możliwy sposób wyrażałyby to, co nieznane, i byłyby mostami łączącymi nas z niewidzialnym brzegiem" (Jung 1976: 368).

6 Stąd u Gastona Bachelarda wyraźna przepaść w nadawaniu znaczeń wartościowym marzeniom na jawie i mało znaczącym snom.

7 Związek impulsu twórczego trzeba łączyć z przedostawaniem się treści z poziomu nieświadomego do świadomego. 
Nie dla wszystkich teoretyków snów źródło i forma nocnych marzeń jest tak „poetycka”. Przyczyny niebanalnych historii sennych nie muszą być przecież aż tak wzniosłe. Niektórzy badacze upatrują powodów dziwaczności i nielogiczności marzeń sennych w ograniczonym udziale dynamizmów myślowych. Na przykład Jan Mazurkiewicz dzieli procesy myślowe na niższe: prelogiczne oraz bardziej rozwinięte czołowo-logiczne. Próbuje on wykazać, że myślenie przyczynowo-logiczne jest „nieczynne” podczas śnienia, a sen jest „jedynym stanem, w którym dynamizmy prelogiczne występują w całej swej czystości" (Mazurkiewicz 1980: 84). Wyciszony płat czołowy byłby odpowiedzialny za niespójność opowieści. Racja zdaje się tkwić tu w tym, że rzeczywiście procesy logiczne są wyłączone lub obniżone. Dzięki temu właśnie, że racjonalne, konkretne, standardowe myślenie zostaje odsunięte, często jest możliwy sam rozkwit kreatywności, twórczości. Z dala od działania i terroru przyczynowo-skutkowego pojawia się miejsce dla swobodnej fantazji.

Nieco inny głos daje Alfred Adler, który metaforyczność i nielogiczność snu widzi jako efekt oddalenia od wspólnego doświadczenia, od "common sense”, na rzecz sposobności do wyrażenia siebie. Powiada on, że „wyobraźnia wyrażająca się metaforą, na zboczu logiki, rozwiązuje problem zgodnie ze stylem życia śniącego" (Adler 1994: 229) ${ }^{8}$. Styl życia, sposób myślenia, jakość refleksji, potencał twórczy w obrazowaniu i nazywaniu byłby tu odpowiedzialny za kształt marzeń sennych.

Erich Fromm natomiast kojarzy sen z zawieszeniem aktywności i ze swobodą „w królestwie wolności moje «jestem» stanowi jedyny system, do którego odnoszą się myśli i uczucia" (Fromm 1977: 47). U Fromma symbole senne (i nie tylko) są trojakiego rodzaju. Pierwszy rodzaj symboli jest umieszczony w relacji wyrazu do przedmiotu, który oznacza (konwencjonalny), drugi rodzaj ma swój początek w konkretnym doświadczeniu jak na przykład w przypadku fobii (akcydentalny), zaś trzeci rodzaj symbolu dotyka wszystkich, zawiera w sobie kojącą bliskość uczucia i myśli.

Większość klasyków mówi o symbolicznym języku marzenia sennego. Łącząc ten język z każdym innym językiem, a także z mitologią. Calvin Hall pokazuje język snu w kontekście mowy poetyckiej, zauważając, że niedosłowności używamy na co dzień w różnych slangach. Jego zdaniem metonimia, synekdocha, metafora i ironia to główne środki wyrazu snu (Hall 1953: 172).

Być może więc we śnie mimowolnie doświadczamy siebie, własnej jednostkowej wyobraźni, kreatywnej aktywności swojego umysłu, którą charakteryzuje skłonność do niesamowitości, do finezji, pokrętności, hiperboli czy oryginału. Jest to „spotkanie”, na które obserwator snu (ego?) przychodzi jak na wykład często surrealistyczny, poetycki, nielogiczny wywód, którego tematem są doświadczenia, myśli i odczuwanie. Może bardziej trafna niż wykład wygłaszany przez cząstkę siebie o sobie i dla siebie - choć znów niedoskonała - byłaby metafora wirtualnej gry, w której sterując w ograniczony sposób własną postacią, przebywam w świecie wykreowanym, narzuconym, determinującym przyjmowane przeze mnie role. Nieudolność porównań uzmysławia tym wyraźniej wyjątkową pozycję Ja we śnie i kłopot w dookreśleniu funkcji i obecności świadomości.

8 Styl życia to u Adlera mniemanie o własnym życiu, które najczęściej jest podmiotowi mniemającemu nieznane, bo nie poddane refleksji. 
Według Fromma nieświadome jest to, co niedostępne rozumieniu. Po zaakceptowaniu psychoanalizy czy ponowoczesności wszelkie poznanie jest w pewnym sensie zintegrowane $z$ niewiadomą, lecz różnica polega na stopniu tej niewiedzy, której skalę na samym dole rozpoczyna ignorancja.

To, że sny w ogóle się śnią, można uznać za rodzaj mowy jaźni o tematach istotnych dla podmiotu czy ducha albo po prostu za potrzebę aparatu psychicznego. Ludzie oraz nauka znieważają fantazje i sny, a zniewaga ta ma swój początek w braku wiedzy lub/i intuicji poznawczej wobec samego siebie. Brak dążenia ku samopoznaniu może wynikać z silnej blokady, rodzaju ograniczenia umysłu, które nie zaprzecza bardzo dobremu funkcjonowaniu na najwyższych stopniach edukacji. Trudniej, gdy jest to życie związane z frustracją, złością, poczuciem winy, fatalną nadopiekuńczością czy histerycznym infantylizmem, który zostaje integralną cechą osobowości. I choć jest przyczyną problemów w relacjach i frustracji właśnie - pozostaje dla człowieka po prostu cząstką Ja.

Gdy brakuje namysłu autoanalitycznego, prób poznania własnej wyobraźni (niekoniecznie psychoanalitycznych), wówczas to sen wykonuje metapracę nad wyobraźnią, relacjami i stylem myślenia. I potrafi to robić z wielką dyskrecją - jeśli nadal pozostajemy wyłącznie w obrębie snów o charakterze symbolicznym, metaforycznym. Zgodnie z myślą Freuda przedstawienie odsunięte od jawnych znaczeń może być rezultatem działania cenzury, ale taki układ sił daje także po prostu możliwość wyboru - podjęcia próby zastanowienia się nad metaforą marzeń sennych lub ich zignorowania. Sen i tak, choć gdzieś hen za horyzontem dnia, przepracowuje treści doświadczenia, nad którymi nikt się nie pochyla. Siła oporu - i tego obecnego we śnie, i tego obecnego w relacji do marzeń sennych wyraża być może stan gotowości, a raczej nieprzygotowania na przyjęcie i integrację niektórych treści.

Dyskrecja snu symbolicznego sprawia, że częstokroć (pomijając sny lękowe i sny „wielkie" ${ }^{\prime \prime}$ ) sen oddala się w niebyt pamięci prawie niezauważony. Wpływ ma na to brzask poranka: zderzenie pracy myśli sennej i myślenia dziennego, sceptycznie pojęta różnica tych porządków czy nawet „nieprzekładalność”. A także to, że sen najczęściej zdarza się raz jeden.

Być może ulotność snu jest obok tego płaszczem ochronnym dla tych, którzy nie chcą wybrać się na nie zawsze łatwą wycieczkę samopoznania. Sen prawie niezauważalnie potrafi pukać do świadomości i pamięci dziennej. A dlatego, że jest to częstokroć pukanie tak wielce delikatne, toteż postrzegane jest jako złudzenie lub (w innej optyce) jako nic nie znaczący szmer, dla którego nie warto podchodzić do drzwi i zapytać „kto tam?”.

\section{II}

Częstokroć natrafiamy na analogię dzieła literackiego i snu, stąd psychoanaliza literatury, gdzie narzędzia analityczne przykłada się do objaśnienia fabuł. Równie ważne jest odwrócenie tej relacji i zbadanie za pomocą wiedzy humanistycznej i narzędzi literaturoznawców marzeń sennych zapisanych w dziennikach i tych opowiadanych przez współczesnych.

\footnotetext{
${ }^{9}$ Termin z myśli Junga.
} 
Dzieło artystyczne bywa ujmowane w różnych teoriach jako niekompletne, co oznacza nie tylko, że - jak chce Ingarden - artefakt serwuje miejsca niedookreślenia, które są nieistotne, bo inaczej byłyby wypełnione. Rzeczywiście ważna jest tu praca fantazji i indywidualnej percepcji dokonywanej przez konkretny podmiot. Artysta daje całe przestrzenie na indywidualny odczyt. Szczególnie dzięki symbolizmowi, który staje się inny w różnych spotkaniach dwóch doświadczeń doświadczenia rozpisanego w dziele czy tekście i doświadczenia żyjącego w osobie przychodzącej na to spotkanie i podejmującej dialog.

Chciałabym zestawić symboliczny potencjał dzieła sztuki i snu. Czy jeśli dzieło jest niekompletne, to sen jest niedośniony? Niedokończony zarówno, gdy przerwał go budzik, jak i wtedy, gdy nie wyczerpał tematu, który na pewno rozpoczął. Dodatkowo w tym miejscu można zapytać, czy świadome spotkanie ze snem koniecznie musi kończyć się fenomenologicznym oddźwiękiem, odtworzeniem intencji nieświadomości jako najważniejszego i najbardziej niedostępnego z nadawców śnienia?

W książce Hanny Segal Marzenie senne, wyobraźnia i sztuka można odczuć, że ważna inspiracja psychoanalizą wpływająca na perspektywę humanistyczną potrzebuje oswobodzeń i przewartościowań ortodoksji, która jest naturalną konsekwencją tego, że pychoanalityczne teorie $u$ podstaw nie bazują na jednostkach zdrowych i w miarę szczęśliwych. I tak Segal przedstawia wiele inspirujących myśli na temat relacji ze snem i relacji ze sztuką, ale kończy na umieszczeniu impulsu twórczego w lęku depresyjnym. Najpierw jednak inspiracje.

Segal pokazuje, że styl marzeń sennych odzwierciedla szeroką gamę naszych relacji (Segal 2003). Sądzę, że przemawia to na korzyść atrakcyjności stylów śnienia u osoby, która żyje w większej liczbie światów: poznaje, czyta, kształci się, fantazjuje, pracuje ze swoją wyobraźnią. Osoby rozwijające się intelektualnie i duchowo mają bardziej metaforyczne sny. Może być to związane z kreatywnością i poziomem abstrakcyjnego rozumowania. Skoro rzeczywiście - jak czytamy u Segal - ludzie są obdarzeni identycznymi popędami, bogactwo wyobrażeniowe zależy od ego.

Autorka mówi za Melanie Klein, że nieświadome fantazje tkwią u podstaw marzeń sennych, symptomów, postrzeżeń, myśli i kreatywności (Segal 2003). Warty uwagi jest fakt, że Klein zauważa jedno źródło, z którego powstaje sen i kreatywność. I znowu wraca pytanie, czy fabuła senna nie jest bardziej ekspresją kreatywności niż zorganizowaną obroną zbrojną ego, które miałoby ustrzec nas przed swobodną ekspresją nieświadomości?

Tylko w jednym miejscu Segal zastanawia się nad ludźmi, którzy są w dobrej komitywie z nieświadomością, „porozumiewają się ze swoimi niewiadomymi fantazjami [...] mają oni świadomość i mogą kontrolować symboliczną ekspresję tkwiących u jej podłoża prymitywnych wyobrażeń" (Segal 2003: 62). Kontrolować poprzez rozumienie, w którym komitywę z samym sobą warto zawrzeć także na poziomie relacji z własnym śnieniem. Psychoanalityczne książki na temat marzeń sennych dostarczają spektakularnych przykładów na to, jak wnikliwe interpretacyjne postępowanie może obnażyć najważniejsze konflikty wadzące psychice w rozwoju ego. Ale takie widowisko nie jest konieczne codziennie.

Treści nieświadomych fantazji są przekazywane zarówno przez sztukę, jak i przez sny. Wartość estetyczną sztuki Freud pojmuje jako umożliwienie 
wyzwolenia przyjemności, nagrodę za zwabienie, przyjemność wstępną (Freud 1991). Sny dzięki wsobnej własności kreatywnej czy też estetycznej właśnie (i nie o piękno tu chodzi) wabią nas do gry wstępnej z wyobraźnią senną. Ciekawość i przyjemność w swobodzie rozumienia snów, zaznajomienie się z ich metaforyką i stylami, potraktowanie jak artefaktu może w konsekwencji autoanalitycznych studiów wzbogacić słownik myślenia o własnych nieświadomych fantazjach. Bez zmartwień o to, że nie zostaną one od razu klarownie wydestylowane z chaosu przedstawień, lecz ze świadomością, że samopoznanie jest narażone na egocentryczne zniekształcenia w recepcji, na przekłamania, które będą wspierać zadomowione fantazmaty. Fantazmaty te, przez opór ze strony świadomości, mogą nie dopuszczać do rozwijania wyobraźni w integrowaniu jej z nieświadomością, czyli z tym, co dotąd nieprzyswojone.

Współczesny badacz snów Calvin Hall interesował się głównie snami większych grup, metodą ilościową, kodowaniem marzeń. Zanotował on ciężki do podważenia wniosek o ciągłości pomiędzy jawą a snem. Badając cykl snów jednej osoby, zauważył, że duża liczba powtórzeń w obrębie jednego studium przypadku tworzy wrażenie nudy. Dobrze ten wątek komentuje Ole Vedfelt, który zauważa, że „materiał Halla stanowili przeważnie ludzie, którzy nie korzystali z terapii i nie pracowali nad własnym rozwojem" (Vedfelt 1998: 145-146). Brak zmian w myśli sennej może bowiem świadczyć o braku rozwoju indywidualnego postrzegania i o zaniedbaniu poszerzania własnej osobowości, a mówiąc językiem psychologii głębi - zaniedbaniu w integracji cienia. Zarówno u Halla, jak i u Alfreda Adlera czy neofreudystów można przeczytać, że w wyobrażeniach sennych częściej występują elementy problemowe, o których śnimy dopóty dopóki takowe one dla nas są, więc pozostają nieprzepracowane.

Choć generalnie pomysł Halla jest poniekąd spójny z psychoanalizą, to jednak w kilku jego założeniach jest jej zaprzeczeniem. Ole Vedfelt, wyliczając punkty, jakie powinien przyjąć interpretator snów według metody Halla, pokazuje, że należy tu uwzględnić, iż „śnimy o tym, o czym musieliśmy myśleć na jawie" (Vedfelt 1998). Przekreśla to teorie o nieświadomych fantazjach obecnych w snach i nowości treści niesionych przez niezaistniałą jeszcze w świadomości myśl, którą może pomyśleć sen. A koronnym dowodem na ich istnienie są przecież głębokie analizy perspektywy psychoanalitycznej.

W odbiorze treści marzenia sennego możemy na chwilę za Barthesem uśmiercić autora i nie będzie to „samobójstwo jako doświadczenie wyobraźni”. Będzie to zrozumienie, że niezrozumienie faktycznej intencji snu nie musi być wadą tej pracy, czyli interpretacji snów. Wolna przestrzeń pojmowania w myśleniu o sobie może poszerzyć konteksty rozumienia własnego doświadczenia powoli lub częściowo.

Dzięki twórczej reprezentacji jednocześnie przybliżamy się do głębszych znaczeń i doznajemy kojącej odległości symbolizacji czy przemieszczeń, którym podlegają te treści w ramach snów i w ramach przedstawień artystycznych. Skoro to jest wspaniałość sztuki, czemu nie może być zaletą śnienia? To rozkwit skojarzeń kieruje procesem odbioru dzieła sztuki, tak jak w psychoanalizie interpretacją snu.

Sen, choć jest ciągiem, szumem, zlepem obrazów, najbardziej przypomina film. Pozostaje jednak po nim jedynie opowieść lub jego zapis, „literacki” ślad. 
Dlaczego więc literaturoznawcy omijają te prywatne (o)powieści? Skoro ta aktywność umysłu jest bez sensu, bez sensu jest też literatura, estetyczna literackość i wszystko to, co ofiarowuje poprzez akt odbioru. Jean-Jacques Rousseau wieki temu przekroczył granicę $\mathrm{w}$ mówieniu o sobie, a wciąż tak mało mamy spowiedzi ze śnienia. Skoro przekonanie o tym, że nie mają zbyt wiele sensu byłoby autentykiem, chyba już dawno w literaturze polskiej ta sfera byłaby obnażona i pogłębiona, ponieważ nikt nie czuł by wahania, by publikować dzienniki snów i ich interpretacje $\mathrm{e}^{10}$.

Istnienie dzieła sztuki, literatury i snu jest niekrzykliwe. Obrazy czekają w galeriach, treści w oprawach, senna pamięć bezszelestnie usuwa obrazy senne, nie przekazując ich pamięci długotrwałej. Poznanie zależy od decyzji - idę do galerii, otwieram książkę, chcę przyjrzeć się snom. Obraz może być nudny, książka grafomańska, sen mało istotny lub niezauważony. Pojawiają się także doświadczenia bardziej krzykliwe. Afektywne wpływy nie pozostawiają nas obojętnymi. Pierwsze zetknięcie z zabawkowym Auschwitz z klocków lego Libery. Przełamania nie są niezauważalne, choć wydaje się, że nie dokonują się bez pierwszego zainteresowania woli skierowanego w stronę poznania.

Może myślenie o kreatywnej strukturze snów i o wejściu w dialog ze śnieniem jest zbyt pozytywne czy nawet odrobinę naiwne, ale wynika ono z subtelnej i niekompletnej opozycji inspirowanej tym, jak swoje rozważania Segal rozwiązuje, mocno akcentuje i kończy:

[...] przez cały czas starałam się podkreślić, jak dalece impuls twórczy wyrasta na podłożu lęków depresyjnych oraz jak ich wyrażenie, w sposób który jest zrozumiały dla odbiorcy, uruchamia procesy typowe dla pozycji depresyjnej: zdolność do symbolizacji, postrzeganie rzeczywistości wewnętrznej i zewnętrznej, zdolność do zniesienia separacji lub oddzielenia (Segal 2003: 138).

Rzeczywiście samo wyrażanie wiąże się z utratą czegoś, co było dotąd nieme, ale jest także oddzieleniem i narodzinami znaczenia, na które można spojrzeć. Impuls twórczy czy impuls, z którego powstaje marzenie senne, nie wyrasta raczej wyłącznie z lęku depresyjnego, ale z potrzeby, pragnienia i wstępnej gotowości na przyjęcie danej treści. Pozycja artysty czy twórcy marzenia sennego i pozycja depresyjna mają swoje miejsca wspólne, ale może je stwarzać różna gleba, różne podłoże kreacji. Nie tylko lękowo-depresyjne, nie tylko konfliktowe, może to być też szczęście, miłość czy zachwyt albo ich pragnienie, jak na przykład w przyjemnych snach o lataniu. Psychoanalityczne rozumienie ma swój konkretny rys wynikający ze sfery, z którą się mierzy, z perspektywy choroby, przez którą najczęściej patrzy i z której w podejściu do snów każdego z nas można wyciągać wspaniałe lekcje, pamiętając jednocześnie o tym, że teorie te mogą być w różny sposób „zbyt jakieś”, aby literalnie przekładać je na sny z życia codziennego w ogóle. U Segal impuls artystyczny dąży do odtworzenia zdekonstruowanej harmonii. A że jest to próba właśnie, toteż dzieło ma zawsze charakter otwarty, niedokończony. Proces twórczy jest sprzężony z pozycją depresyjną: próbą

${ }^{10}$ Własne sny publikowali według mojej wiedzy: Jan Lechoń, Maria Dąbrowska, Marian Marzyński, Adam Wiedemann oraz Henryk Bereza. Nie ma jednak wśród tych nazwisk osoby, która rzetelnie przyjrzałaby się własnym snom w kontekście samopoznania. Jedynej próby dokonuje w mojej ocenie Krystyna Sakowicz. 
odzyskania utraconego świata. Wydaje się to integralnie związane z powrotem wypartego, z tym, że sen to „wydzieliny stłamszonych w zarodku myśli”, z odrzuceniem możliwości, że senne nieświadome to nie tylko to, co było niegdyś świadome, ale być może także po prostu to, co jeszcze niezrozumiane, niepomyślane, nowe.

Psychoanaliza jest hermeneutyką, a symbol/przedstawienie zawsze odsyła poza siebie - do innego znaczenia, ale także do uczuć mu towarzyszących. Stąd też ogromna rola kontekstu i emocji obecnych w marzeniu sennym. Fromm podzielił symbole na konwencjonalne, akcydentalne i uniwersalne (Fromm 1977). Konwencjonalne działają w języku, uniwersalne można porównać do archetypów, natomiast akcydentalne odwołują się do indywidualnego doświadczenia i częstokroć nadają idiosynkratyczny charakter marzeniom sennym.

Nie zawsze sen przekazuje arcyważne treści prosto z samego rdzenia wielkiej nieświadomości, tak samo jak nie każde dzieło literackie mówi o ponadjednostkowej właściwości jaźni. Są sny wielkie, są arcydzieła, sny mniej ważne i grafomania. „Wielkie dzieło jest jak sen, który mimo swej jawności, sam siebie nie interpretuje" (Jung 1976: 402). Tak samo zwykły sen jest jak mała, wprowadzająca do naszego życia książeczka.

\section{Literatura:}

Adler A., 1994, Sens życia, tłum. M. Kreczkowska, Kraków.

Fiała E., 1991, Modele freudowskiej metody badania dzieła, Lublin: Towarzystwo Naukowe Katolickiego Uniwersytetu Lubelskiego.

Freud Z., 1986, Pisarz i fantazjowanie [w:] Teoria badań literackich za granica. Antologia, t. 2:

Od przełomu antypozytywistycznego do roku 1945, wyb. S. Skwarczyńska, Kraków: Wydawnictwo Literackie.

Freud Z., 1991, Poeta i fantazjowanie [w:] K. Pospiszyl, Zygmunt Freud. Człowiek i dzieło, wyb., tłum. B. Kocowska et al., Wrocław: Zakład Narodowy im. Ossolińskich.

Freud Z., 1995, Wykład ze wstępu do psychoanalizy. Nowy cykl, tłum. P. Dybel, Warszawa: Wydawnictwo KR.

Freud Z., 2006, Wstęp do psychoanalizy, tłum. S. Kempnerówna, W. Zaniewicki, Warszawa: PWN.

Freud Z., 2007, Objaśnienie marzeń sennych, tłum. R. Reszke, Warszawa: Wydawnictwo KR. Fromm E., 1997, Zapomniany język. Wstęp do rozumienia snów, baśni i mitów, tłum. J. Marzęcki, Warszawa: PIW.

Hall C., 1953, Cognitive Theory of Dream Symbol, "The Journal of General Psychology” No. 48. Jung C.G., 1976, Archetypy i symbole. Pisma wybrane, wyb., tłum. J. Prokopiuk, Warszawa: Czytelnik.

Mauron C., 1976, Wprowadzenie do psychokrytyki [w:] Wspótczesna teoria badań literackich za granica. Antologia, t. 2: Strukturalno-semiotyczne badania literackie, literaturoznawstwo porównawcze, w kręgu psychologii głębi i mitologii, red. H. Markiewicz, Kraków: Wydawnictwo Literackie.

Mazurkiewicz J., 1980, Zarys psychiatrii psychofizjologicznej, Warszawa: Państwowy Zakład Wydawnictw Lekarskich.

Segal H., 2003, Marzenie senne, wyobraźnia i sztuka, tłum. P. Dybel, Kraków: Universitas.

Vedfelt O., 1998, Wymiary snów. Istota, funkcje i znaczenie marzeń sennych, tłum. P. Billing, Warszawa: Eneteia. 


\section{Abstrakt}

W artykule Twórcze opowieści nocy - zaniedbane przedstawienia senne porównuję powstawanie snów z procesem twórczym artysty. Proponuję oswobodzenie snów z psychoanalitycznej wykładni i zainteresowanie nimi jako podstawową kreatywną funkcją umysłu.

\section{Słowa kluczowe}

badania nad snem, psychoanaliza, Hanna Segal, autoanaliza

\section{Summary}

Creative Night Story - Neglected Dreams

In the article Creative night story - neglected dreams I compare the formation of dreams to the creative process of an artist. I propose the liberation of theory of psychoanalysis and interests in dreams as a basic creative function of mind.

\section{Keywords}

dream studies, psychoanalysis, Hanna Segal, autoanalysis 